\title{
ARTYKUŁY
}

http://dx.doi.org/10.15762/ZH.2018.05

MONIKA TOMKIEWICZ

(Instytut Pamięci Narodowej

Oddziałowa Komisja Ścigania Zbrodni przeciwko Narodowi Polskiemu w Gdańsku)

\section{ZaKŁad WYCHOWAWCZY DLA POLSKICH CHŁOPCÓW W WEJHEROWIE W OKRESIE OKUPACJI NIEMIECKIEJ ${ }^{*}$}

Słowa kluczowe: Neustadt, niemieckie placówki wychowawcze dla dzieci polskich, sierocińce, tereny włączone do Trzeciej Rzeszy, życie codzienne na Pomorzu Gdańskim w okresie okupacji niemieckiej

W dniu 9 IX 1939 r. ok. godziny 10.00 Wejherowo zostało zajęte przez żołnierzy niemieckich z 207 dywizji piechoty Karla von Tiedemanna (dywizja ta liczyła 160 oficerów i 660 podoficerów), 32 pułku Grenzwache von Bothmera, batalionu SS-Heimwehr Danzig ${ }^{1}$ majora von Rittberga i 5 pułku kawalerii Dienera. Administracyjnie ziemia wejherowska weszła w skład Okręgu Rzeszy Gdańsk-Prusy Zachodnie, a miasto otrzymało nazwę Neustadt (Westpreussen). W miejsce zlikwidowanych polskich instytucji kulturalnych i opiekuńczych Niemcy stosunkowo szybko zaczęli wprowadzać własne jednostki. Władze okupacyjne bardzo sprawnie przejęły również budynki gospodarcze

* Tekst powstał na bazie materiałów śledztwa Oddziałowej Komisji Ścigania Zbrodni przeciwko Narodowi Polskiemu w Gdańsku. Pierwsza korespondencja w tej sprawie wpłynęła do byłej Okręgowej Komisji Badania Zbrodni Hitlerowskich w Gdańsku w maju 1990 r. Od tego roku w Komisji prowadzone było postępowanie sprawdzające. Śledztwo w tej sprawie zostało wszczęte 25 I 1997 r. i zawieszone 29 I 1999 r. w związku z likwidacją instytucji. Dnia 9 XI 2000 r. prokurator podjął z zawieszenia śledztwo, które zakończyło się wydaniem postanowienia o umorzeniu śledztwa w dniu 26 IX $2002 \mathrm{r}$.

${ }^{1}$ SS-Heimwehr Danzig - niemiecka formacja wojskowa Waffen-SS działająca w latach 1939-1940. Złożona z członków III batalion 4. pułku SS-Totenkopf „Ostmark” nielegalnie przerzuconych do Gdańska oraz ok. 1500 ochotników z Gdańska. SS-Heimwehr Danzig weszła w skład Brygady gen. Friedricha Eberhardta. Dnia 1 IX 1939 r. uczestniczyła w ataku na budynek Poczty Polskiej w Gdańsku, a potem w dwóch nieudanych atakach na Wojskową Składnicę Tranzytową na Westerplatte. Członkowie tej jednostki brali też udział w masowych egzekucjach w Lasach Szpęgawskich, zob. Rolf MichaeLIS, SS-Heimwehr Danzig 1939, Warszawa 2003, s. 7-9; P. Krauss, Damals. Heimwehr Danzig. Erinnerungen und Begegnungen, Coburg 1982, bez pag.; Jan Daniluk, SS w Gdańsku, Gdańsk 2013, s. 97-98. 
należące przed wojną do Krajowego Zakładu Opieki Społecznej przy Adolf-Hitler-Straße 279 (dawniej i obecnie ul. Jana Sobieskiego 279) i przeznaczyły je na zakwaterowanie dla oddziałów wojskowych.

Obiekty te zostały zbudowane w latach $1881-1883$ z przeznaczeniem na szpital psychiatryczny mogący przyjąć na leczenie ok. 400 pacjentów z prowincji Prusy Zachodnie. Kompleks obejmował kilkanaście budynków mieszczących się przy drodze z Wejherowa do Bolszewa. Na ten cel ofiarowano 25 mórg lasu miejskiego i 160 mórg ziemi prywatnej. Po zakładzie w Świeciu był to drugi tego rodzaju nowoczesny szpital na terenie prowincji. W latach 1920-1939 stał się on częścią nowo utworzonego Krajowego Zakładu Opieki Społecznej. Pacjentami placówki byli głównie Polacy oraz rosyjscy i niemieccy jeńcy wojenni. Dnia 15 IX 1933 r. lecznica została ostatecznie zlikwidowana, a chorzy zostali przeniesieni do Zakładów Psychiatrycznych w Świeciu i Kocborowie ${ }^{2}$. W dniu 20 IX 1933 r. pięć budynków przeznaczono na zakwaterowanie dla żołnierzy Batalionu Morskiego (przemianowanego w 1937 r. na 1 Morski Batalion Strzelców). W jednym z gmachów znajdowała się Szkoła Podstawowa dla Głuchoniemych. Po zakończeniu pierwszej wojny światowej, gdy szkoły dla dzieci głuchych w Człuchowie i Malborku znalazły się poza granicami państwa polskiego, zaistniała potrzeba utworzenia tego typu placówki dla dzieci z Okręgu Pomorskiego. Starostwo Krajowe w Toruniu podjęło decyzję o utworzeniu z dniem 1 IX 1921 r. szkoły dla dzieci głuchych pod nazwą Pomorski Krajowy Zakład dla Głuchoniemych. Lokum dla zakładu miało się znajdować $w$ Wejherowie w kilku wydzielonych budynkach po szpitalu psychiatrycznym. Organizatorem i pierwszym kierownikiem zakładu został Leonard Retzlaff. Szkoła umieszczona została w budynku nr 8, a internaty w budynkach $\mathrm{nr} 10 \mathrm{i} 12$. W pierwszym roku szkolnym funkcjonowania placówki (1921/1922) liczba dzieci głuchych wynosiła 100, w tym 40 dziewcząt i 60 chłopców, którzy byli nauczani przez 12 pedagogów³. Od 1923 r. w Wejherowie, w pobliżu koszar wojskowych przy ul. Jana Sobieskiego, w niedalekim

${ }^{2} \mathrm{~W}$ okresie międzywojennym w Krajowym Zakładzie Psychiatrycznym w Kocborowie przebywało ok. 1200 chorych kobiet i mężczyzn. Pierwsza selekcja osób chorych przeznaczonych do likwidacji w ramach „akcji T4” nastąpiła już we wrześniu 1939 r. Poza likwidacją chorych w Lasach Szpęgawskich uśmiercani oni byli również w kostnicy zakładu. Jesienią 1939 r. na teren zakładu przewieziono chorych ze zlikwidowanego szpitala w Świeciu. Część z nich także została zamordowana w Lasach Szpęgawskich. Przypuszczalnie część chorych została wywieziona do pobliskich Skarszew i tam zamordowana. Zob. Oddziałowa Komisja Ścigania Zbrodni przeciwko Narodowi Polskiemu w Gdańsku (dalej cyt. OK.Gd.), sygn. Ko 187/73, postępowanie sprawdzające $\mathrm{w}$ sprawie zbrodni popełnionych na pacjentach szpitala psychiatrycznego w Kocborowie.

${ }^{3}$ Historia Ośrodka Szkolno-Wychowawczego $n r 2$ dla Głuchych im. J. Siestrzyńskiego w Wejherowie, Wejherowo 1991, s. 7-17. 
sąsiedztwie budynków Pomorskiego Krajowego Zakładu dla Głuchoniemych mieścił się Zakład Wychowawczy Dzieci Syberyjskich ${ }^{4}$.

W latach trzydziestych XX w. Zakład Wychowawczy Dzieci Syberyjskich oraz Pomorski Krajowy Zakład dla Głuchoniemych zostały przemianowane na Krajowy Zakład Opieki Społecznej. W ich skład wchodziły wówczas Szkoła Podstawowa dla Dzieci Głuchych oraz Zakład Wychowawczy. Dodatkowo w 1933 r. do wejherowskiej placówki zostały przeniesione dzieci, personel i dyrekcja z Pomorskiego Zakładu Poprawczego i Zakładu dla Krajowo-Ubogich w Chojnicach ${ }^{5}$. We wrześniu 1939 r. dzieci głuchonieme przebywały jeszcze na wyjazdach wakacyjnych poza ośrodkiem, a w budynkach pozostali jedynie pensjonariusze Zakładu Wychowawczego. Polscy nauczyciele, m.in. Józef Kotewicz i Józef Kamiński, będący oficerami rezerwy, zostali powołani do czynnej służby wojskowej w oddziałach I Morskiego Pułku Strzelców w Wejherowie ${ }^{6}$.

$\mathrm{Na}$ początku niemieckiej okupacji na terenach włączonych do Trzeciej Rzeszy przejęto pod zarząd wszystkie polskie sierocińce i zakłady wychowawcze. Było to zgodne z wytycznymi zamieszczonymi w opracowaniu przygotowanym przez Urząd Polityczno-Rasowy w listopadzie 1939 r. zatytułowanym „Sprawa traktowania ludności byłych polskich obszarów z rasowo-politycznego punktu widzenia”, w którym zalecono wyłączenie z przesiedleń dzieci „pochodzących od niemieckiego przodka”, które powinny być wychowywane na terenie Rzeszy w odpowiednich zakładach wychowawczych wzorowanych na dawnym poczdamskim Domu Sierot w warunkach dyscypliny wojskowej lub też w niemieckich rodzinach?

Prowadzona na szeroką skalę polityka władz niemieckich mająca na celu zniszczenie na Pomorzu wszelkich przejawów kultury polskiej polegała również na przeprowadzaniu selekcji rasowej dzieci pochodzących ze wszystkich środowisk ze szczególnym naciskiem położonym na dzieci przebywające w polskich zakładach opiekuńczych i rodzinach zastępczych. We wszystkich placówkach wychowawczych i opiekuńczych (tj. m.in. w Wejherowie, Kamie-

\footnotetext{
${ }^{4}$ Regina Osowicka, Matki mdlały z rozpaczy, sieroty z głodu jadły śnieg. Odyseja „polskich dzieci syberyjskich" przez Japonię do Wejherowa, Dziennik Bałtycki, nr 321 z 2 XII 1994 r., s. 7.

${ }^{5}$ Henryk Porożyński, Zakład Poprawczy w Chojnicach w latach 1885-1985, Słupsk 1991, s. $19-28$.

${ }^{6}$ Spośród innych osób zatrudnionych w szkole w Wejherowie wymienić należy: Teofila Lisakowskiego, Edmunda Fenskego, Józefa Idzikowskiego, Brunona Mejera, Jana Bieńkowskiego, Jana Maciejewskiego, ks. Józefa Bartela, Aleksę Kolasińską, Bronisławę Wryczankę, Marię Tomaszewską, Elżbietę Szuttównę, Franciszka Szanka, zob. Józef Kotewicz, Pięćdziesięciolecie ośrodka szkolno-wychowawczego nr 2 dla głuchych $w$ Wejherowie (Biblioteka Muzeum Piśmiennictwa i Muzyki Kaszubsko-Pomorskiej w Wejherowie), Wejherowo 1983, s. 66.

${ }^{7}$ Roman Z. Hrabar, Janczarowie XX wieku, Katowice 1983, s. 18-19; Włodzimierz JAstrzęBski, Jan Sziling, Okupacja hitlerowska na Pomorzu Gdańskim w latach 1939-1945, Gdańsk 1979, s. 167-171.
} 
niu Pomorskim, Kietrzu i Grodkowie) personel polski zastąpiono niemieckim i wprowadzono zakaz używania języka polskiego. Wiele dzieci w placówkach tych przebywało jeszcze przed wybuchem wojny, ale zaznaczyć należy, że do ośrodków tych trafiały przede wszystkim te odbierane rodzicom, którzy nie chcieli podpisać volkslisty ${ }^{8}$, odbierane rodzicom zastępczym lub będące na wychowaniu krewnych, dzieci zabitych partyzantów lub zakładników, pochodzące $z$ małżeństw mieszanych, gdzie opiekę nad nimi powierzano stronie niemieckiej. Bardzo często dzieci przed zniemczeniem poddawane były badaniom zdrowotnym, psychologicznym i rasowym. Bardzo istotna była również inteligencja i cechy charakteru. Wiek dzieci, które mogły przebywać w zakładach wychowawczych, określono na 8-10 lat, przyjmując, że tylko w tym okresie życia możliwe jest prawidłowe zakończenie procesu germanizacyjnego ${ }^{9}$.

W wejherowskiej placówce jeszcze we wrześniu 1939 r. administracja niemiecka rozwiązała umowy ze wszystkimi polskimi nauczycielami, wychowawcami i personelem pomocniczym zatrudnionym w przedwojennej Szkole Podstawowej dla Głuchoniemych. Przebywające w niej dzieci oraz sprzęt wykorzystywany do nauki zostały przewiezione do podobnej placówki zorganizowanej w Bydgoszczy. Najbardziej w tym okresie ucierpiała biblioteka szkolna (mieszcząca się w budynku oznaczonym nr 8), z której spalonych zostało ok. 5000 woluminów polskich książek. Najcenniejsza część księgozbioru została ukryta na strychu w bloku nr 4 przez polskich nauczycieli szkoły: Konstantego Willmę, Jana Nacmera i Teodora Smagałę ${ }^{10}$.

Od listopada 1939 r. w części budynków wykorzystywanych przed wojną przez Zakład Opieki ${ }^{11}$ stacjonowały dwa oddziały Wehrmachtu Wehrkreis XX.

${ }^{8}$ W dniu 4 III 1941 r. ogłoszona została ustawa o niemieckiej liście narodowościowej (Deutsche Volksliste) na terenie okupowanej Polski, zob. Karol Marian PosPieszalski, Niemiecka Lista Narodowa w „Kraju Warty” (Documenta Occupationis Teutonicae, t. 4), Poznań 1949; Ryszard Kaczmarek, Niemiecka polityka narodowościowa na Górnym Ślasku (1939-1945), Pamięć i Sprawiedliwość, 2004, nr 2 (6), s. 115-138.

${ }^{9}$ Edward Leszczyński, Sonderbehandlung. Zbrodnia na polskich dzieciach, Wrocław 2014, s. 30-34; Konrad Ciechanowski, Okupacyjne losy polskich dzieci i młodzieży na Pomorzu Gdańskim, [in:] Dzieci i młodzież w latach drugiej wojny światowej, red. Czesław PilıchowSKI, Warszawa 1982, s. 289-298; Józef Wnuk, Helena Radomska-Strzemecka, Dzieci polskie oskarżają 1939-1945, Warszawa 1961, s. 7-12; Historia Wejherowa, red. Józef BonzYszKowski, Wejherowo 1998, s. 384; Roman Z. HrabaR, Hitlerowski rabunek dzieci polskich. Uprowadzanie i germanizowanie dzieci polskich w latach 1939-1945, Katowice 1960, s. 1.

${ }^{10}$ Według relacji nauczyciela Konstantego Willmy budynek ten spłonął w 1945 r. z całą zawartością. Zygmunt Milczewski, Wejherowo i powiat morski wrzesień 1939 - maj 1945 (kronika), Gdańsk 1991, s. 31; Ziemia wejherowska, Gdańsk 1980, s. 182; J. KотеwiCZ, op.cit., s. 67.

${ }^{11}$ OK.Gd., sygn. S 6/00/Zn, śledztwo w sprawie dyskryminacji dzieci polskich w zakładzie wychowawczym w Wejherowie w okresie okupacji hitlerowskiej, protokół przesłuchania świadka Antoniego Konkel, 11 IV 1994 r., t. 1, s. 81-83; sygn. S 77/10/Zn, śledztwo w sprawie zastrzelenia w dniu 10 IX 1939 r. na dziedzińcu więzienia w Wejherowie polskich jeńców wojennych 
Od 1 XI 1939 r. koszary wejherowskie przy Adolf-Hitler-Straße 279 zajmował 62 oddział artylerii (Artillerie-Ersatz-Abteilung 62). Dostosowanie terenu i budynków dla potrzeb wojskowych było bardzo pracochłonne. Ze względu na zbliżającą się zimę potrzebne były przede wszystkim miejsca przeznaczone do garażowania samochodów i dział pancernych. Stan techniczny budynków poszpitalnych był w większości zły. W dwóch salach przeznaczonych na zakwaterowanie dla wojska istniało niebezpieczeństwo oberwania się sufitu. Wymagany był natychmiastowy remont. Dawna kuchnia zakładowa była przestarzała i zdecydowanie niewystarczająca na potrzeby tak dużej liczby żołnierzy ${ }^{12}$.

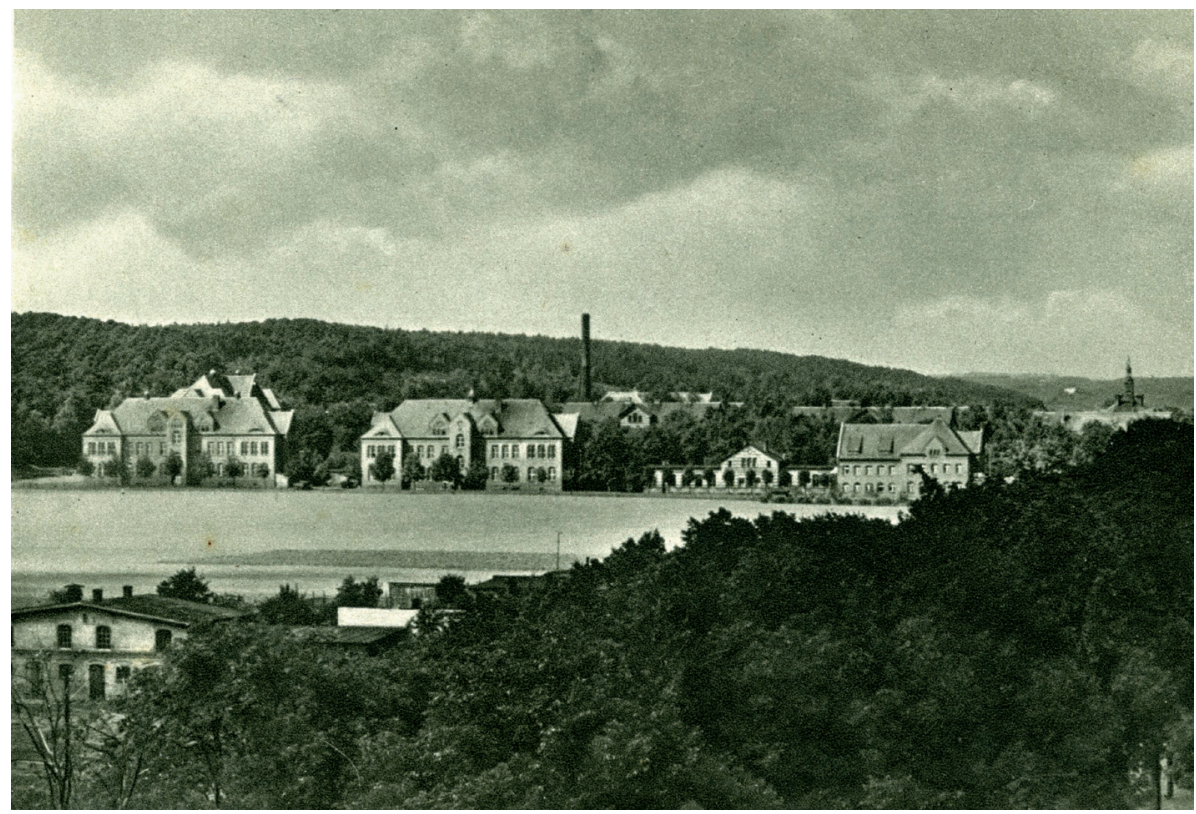

1. Kompleks budynków, w których mieścił się Zakład Wychowawczy dla chłopców w Wejherowie w latach 1939-1943, obecnie siedziba Ośrodka Szkolno-Wychowawczego nr 1 im. J. Korczaka, Muzeum Piśmiennictwa i Muzyki Kaszubsko-Pomorskiej w Wejherowie

W kompleksie budynków przy Adolf-Hitler-Straße niezagospodarowane przez wojsko pozostały jedynie bloki oznaczone numerami 2 i 4 oraz przyzakładowe gospodarstwo rolne. W obu obiektach utworzono nowe instytucje: w dwupiętrowym budynku Zakład Wychowawczy dla polskich chłopców

Aleksandra Wikieła i Józefa Nowaczyka przez funkcjonariuszy gdańskiego gestapo, Pismo Krajowego Urzędu Kryminalnego Badenia-Wirtembergia, t. 2, s. 290-294; Archiwum Państwowe w Gdyni, Krajowe Zakłady Opieki Społecznej w Wejherowie 1920-1939, zespół 223.

${ }^{12}$ Prokuratura przy Sądzie Krajowym w Hanowerze [Staatsanwaltschaft bei dem Landgericht Hannover], Proces Kurta Eimanna i Georga Erbrechta, sygn. 2 Js 614/62, 9 I 1963 r., s. 6256; Bundesarchiv Ludwigsburg, sygn. B 162/7786 Sonderheft Piaśnica. 
(Erziehungsanstalt Neustadt Westpreussen), a w pawilonie parterowym ośrodek poprawczy dla chłopców z Gdańska (Gauerziechungsheim für Jungen Neustadt Westpreussen). W gmachu dwupiętrowym na parterze znajdowały się kuchnia, stołówka, kancelaria, pomieszczenia biurowe i klasy szkolne. $\mathrm{Na}$ piętrze natomiast były sypialnie chłopców i łazienki. Budynki koszarowe zostały oddzielone od zakładu ogrodzeniem z metalowej siatki.

W latach 1939-1943 w wejherowskim zakładzie w oddzielnych budynkach przebywały dzieci polskie i niemieckie (młodzież z Gdańska). Byli to chłopcy w wieku od 4 do 21 lat urodzeni między rokiem 1918 a 1935. Pochodzili oni z terenów byłego województwa pomorskiego, głównie z Bydgoszczy, Grudziądza, Torunia, Gdyni, Starogardu Gdańskiego, Golubia, Dobrzynia i Kartuz. Dzieci polskie kierowane były do Zakładu Wychowawczego w Wejherowie przez policyjne władze niemieckie, tj. Miejski Urząd do Spraw Nieletnich (Stadtjugendamt), Powiatowy Urząd do Spraw Nieletnich (Kreisjugendamt), Urząd Opieki Społecznej (Fürsorgenamt), Komisarza Obwodowego (Amtskommissar). Szczegółowe informacje na temat osadzonych w zakładzie chłopców zawarte zostały w „Księdze ewidencyjnej (Aufnahmebuch)”. Wpisów do księgi dokonano w językach polskim i niemieckim. Księga zawiera następujące dane: imię i nazwisko, miejsce urodzenia i powiat, datę urodzenia, stan cywilny, wyznanie, zawód i miejsce zamieszkania rodziców, nazwisko opiekuna sądowego, nazwę urzędu kierującego i przyczynę zatrzymania, datę przybycia, datę odejścia, przyczynę odejścia, rodzaj zwolnienia oraz uwagi. Można zauważyć, że w przypadku starszych chłopców adnotacje najpierw wpisywane były $\mathrm{w}$ języku polskim, a potem kontynuowane $\mathrm{w}$ języku niemieckim. Zatem przynajmniej część chłopców przebywającym przed wojną w zakładzie pozostała w nim po wkroczeniu Niemców. Najwcześniejsza data przyjęcia chłopca do zakładu to 26 II 1936 r. (Zygfryd Kotlecki, ur. 14 V 1918 r. w Toruniu, skierowany do wejherowskiego zakładu przez Zarząd Miasta Torunia). Ostatni wpis w języku polskim został dokonany 19 VIII 1939 r. i dotyczy Mariana Matuszewskiego, ur. 19 III 1923 r. Pierwszy wpis sporządzony przez administrację niemiecką dotyczył Gerarda Sroczyńskiego (ur. 6 V 1924 r. w Grudziądzu) i dokonano go 13 marca $1940 \mathrm{r}$. Ostatnie zanotowane w księgach przyjęcie do zakładu, oznaczone numerem kolejnym 2849, nastąpiło 28 X 1943 r. i dotyczyło Franciszka Bębenka, ur. 12 VI 1926 r. w Elblągu ${ }^{13}$.

${ }^{13}$ Aufnahmebuch Erziehungsanstalt Neustadt, bez pag., nr 1-2849, OK.Gd., sygn. S 6/00/Zn, załącznik do akt nr 1, protokół przesłuchania świadka Antoniego Konkela, 31 I 1992 r., t. 1, s. 59-60; Józef Wiткошsкi, Dziecko w systemie hitlerowskim, [in:] Człowiek, populacja, środowisko. Prace Dolnośląskiego Centrum Diagnostyki Medycznej „Dolmed” we Wrocławiu, Wrocław 1988, s. 35; idem, Hitlerowski obóz koncentracyjny dla małoletnich $w$ Łodzi, Wrocław 1975; Konrad Ciechanowski, Obozy hitlerowskie na Pomorzu w latach 1939-1945 nie podlegajace Inspektoratowi Obozów Koncentracyjnych - stan badań i postulaty badawcze, [in:] Sesje nauko- 


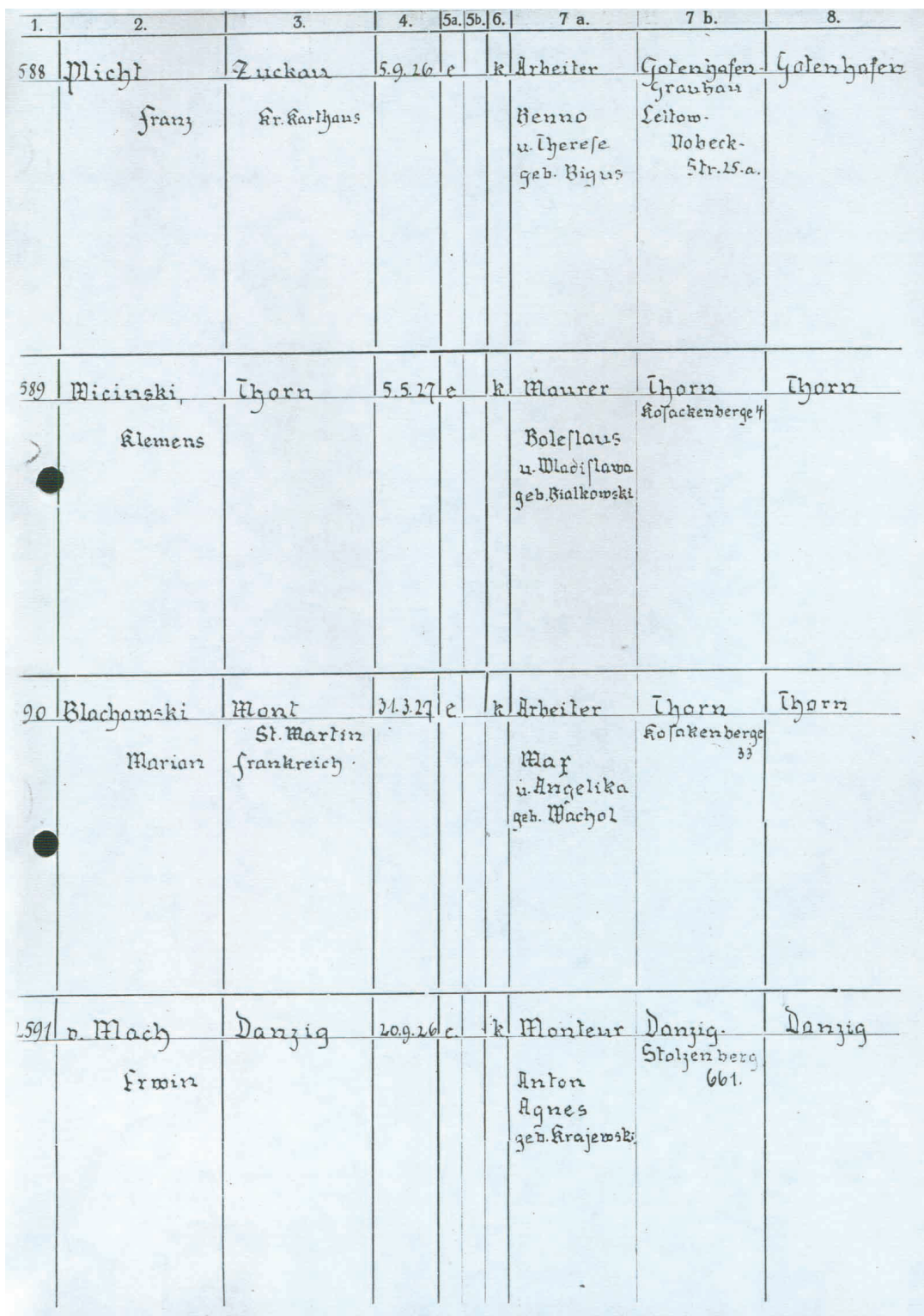

2. Fragment księgi rejestracyjnej Zakładu Wychowawczego w Wejherowie z lat niemieckiej okupacji, Oddziałowa Komisja Ścigania Zbrodni przeciwko Narodowi Polskiemu w Gdańsku, sygn. S 6/00/Zn, śledztwo w sprawie dyskryminacji dzieci polskich w zakładzie wychowawczym w Wejherowie w okresie okupacji hitlerowskiej, Załącznik nr 1 do akt

we Okręgowej Komisji Badania Zbrodni przeciwko Narodowi Polskiemu w Gdańsku, Gdańsk 1987, s. 21-24, achiwum podręczne OK.Gd., materiały niepublikowane; Henryk Porożý́ski, Zakład poprawczy w Chojnicach w latach 1885-1985, Słupsk 1991, s. 70. 
Powody umieszczenia dzieci w placówce wychowawczej były rozmaite. Począwszy od osadzenia w zakładzie sprawców drobnych czynów karalnych, przez dzieci z likwidowanych przykościelnych sierocińców, kończąc na dzieciach odebranych polskim rodzicom za niepodpisanie niemieckiej listy narodowościowej. Przykładowo Bronisław Weinchold z czwórką swojego rodzeństwa (11-letnią Gertrudą, 6-letnim Mieczysławem, 4-letnim Maksymilianem i 2-letnim Janem) w październiku $1940 \mathrm{r}$. zostali nocą pod nieobecność rodziców zabrani przez funkcjonariuszy Schutzpolizei bezpośrednio z ich domu w Toruniu. Dwójka rodzeństwa: Bronisław i Mieczysław zostali następnie przewiezieni do wejherowskiego zakładu. Z kolei podopieczny sierocińca prowadzonego przez siostry zakonne z Chełmna nad Wisłą Waldemar Bojanowski po rozwiązaniu we wrześniu 1939 r. tej placówki został z innymi dziećmi umieszczony w punkcie zbornym dla jeńców wojennych zlokalizowanym w miejscowym kościele garnizonowym. Następnie przez obóz w Potulicach i obóz Stutthof trafił ostatecznie do Zakładu Wychowawczego w Wejherowie ${ }^{14}$.

Dzieci umieszczone w wejherowskiej placówce przed odebraniem ich rodzicom nie były poddawane żadnym badaniom rasowym pod kontem ustalenia ich przydatności do procesu germanizacji. Według danych z 31 IV $1940 \mathrm{r}$. liczba polskich dzieci przebywających w zakładzie wynosiła 101 chłopców narodowości polskiej. Świadkowie wspominają jednak, że liczba chłopców umieszczonych w tej placówce przez cały okres jej działalności mogła wynosić nawet 300 . W liczbie 101 podopiecznych ujęto również 31 chłopców, którzy później zostali przewiezieni do Obozu dla Dzieci i Młodzieży Polskiej w Łodzi (Polen Jugendverwahrlager der Sicherheitspolizei in Litzmannstadt) przy ul. Przemysłowej ${ }^{15}$. Placówka ta stanowiła prewencyjny obóz policji bezpie-

${ }^{14}$ OK.Gd., sygn. S 6/00/Zn, protokół przesłuchania świadka Bronisława Weincholda, 6 XI 1991 r., t. 1, s. 33-34; protokół przesłuchania świadka Waldemara Bojanowskiego, 12 III 1992 r., t. 1, s. 41.

${ }^{15}$ Od 22 II do 23 VII 1943 r. z Zakładu Wychowawczego w Wejherowie do Obozu dla Dzieci i Młodzieży Polskiej w Łodzi przy ul. Przemysłowej przetransportowano następujących chłopców: Ludwika Kwiatkowskiego, ur. 8 IX 1929 r. w powiecie Rypin; Waldemara Bojanowskiego, ur. 12 V 1930 r.; Czesława Sadłowskiego, ur. 20 VII 1928 r.; Alojzego Grzuchowskiego, ur. 6 VI 1928 r. w Grudziądzu; Józefa Olejniczaka, ur. 19 III 1928 r. w Lille; Ryszarda Rogowskiego, ur. 14 V 1927 r. w Grudziądzu; Bernarda Radtke, ur. 8 XII 1931 r.; Bronisława Weincholda; Mieczysława Weincholda, ur. 3 VIII 1934 r. w Toruniu; Stanisława Szpalerskiego vel Spolerskiego, ur. 4 VIII 1929 r. w Metz; Gracjana Ciechanowskiego, ur. 10 VII 1931 r. w Świeciu; Jerzego Gruzewskiego, ur. 16 IX 1927 r. w Bydgoszczy; Franciszka Buszyńskiego, ur. 22 VII 1932 r.; Zdzisława Skopiaka, ur. 28 VI 1935 r.; Stanisława Formellę, ur. 18 XI 1930 r.; Stanisława Basia, ur. 26 XII 1929 r. w Serocku; Józefa Basia, ur. 25 XI 1932 r. w Serocku; Henryka Basia, ur. 1 VIII 1934 r. w Serocku; Zbigniewa Byszewskiego, ur. 24 X 1930 r. w Toruniu; Józefa Kowalskiego, ur. 30 IX 1931 r. w Grudziądzu; Władysława Bedro, ur. 25 II 1929 r. w Grudziądzu; Stanisława Maja, ur. 5 II 1931 r. w Toruniu; Tadeusza Banasika, ur. 8 X 1933 r. w Toruniu; Leona Banasika, ur. 22 VII 1936 r.; Józefa Kukso, ur. 10 XI 1928 r. powiecie Płock; Eugeniusza Za- 
czeństwa dla młodzieży polskiej o zaostrzonym rygorze utworzony pilnym zarządzeniem Reichsführera SS Heinricha Himmlera z 28 XI 1942 r. Trafiały do niej głównie dzieci rodziców należących do ruchu oporu i czynnie walczących $\mathrm{z}$ okupantem oraz te, które proces resocjalizacyjny częściowo odbyły $\mathrm{w}$ innych zakładach. Przez łódzki lager od grudnia 1942 r. do 18 I 1945 r. przeszło ok. 13 tysięcy dzieci polskich, z których ocalało zaledwie tysiąc osób ${ }^{16}$.

Życie w zakładzie toczyło się według określonego rytmu. Dzień rozpoczynał się o godzinie 6.00 od gimnastyki i toalety porannej. Następnie dzieci otrzymywały śniadanie. Potem zwykle odbywał się apel poranny i zajęcia szkolne prowadzone w języku niemieckim. W czasie apelu wychowawcy przydzielali chłopców do poszczególnych prac. Około godziny 12.00 następowała przerwa obiadowa. Po niej chłopcy kontynuowali prace aż do godziny 18.00. Wieczorem przeprowadzany był kolejny apel podsumowujący cały dzień. Do godziny 20.00 chłopcy musieli być już w swoich łóżkach ${ }^{17}$.

W czasie pobytu w zakładzie część chłopców była sezonowo urlopowana i kierowana do prac fizycznych w gospodarstwach rolnych okolicznych Niemców. Warunki bytowe i pracy w gospodarstwach były uzależnione od podejścia poszczególnych bauerów. Większość dzieci nie była jednak karana fizycznie. Praca, którą wykonywali, była wyczerpująca i trwała od rana do wieczora. Najczęściej dzieci wykorzystywane były do prac polowych związanych z sadzeniem, okopywaniem i zbieraniem ziemniaków, pieleniem grządek, dostarczaniem paszy dla bydła i prac porządkowych na terenach przydomowych. Niektóre dzieci - tak jak np. Franciszek Topolski, który pracował u niemieckiego gospodarza o nazwisku Radtke w Żarnowcu, i Jan Józef Wiśniewski zatrudniony w gospodarstwie w Letnim Dworze u Antona Langa - otrzymywali niewielkie wynagrodzenie za pracę w wysokości od 4 do 10 marek miesięcznie. Również te dzieci, które nie były zatrudniane w niemieckich gospo-

leśkiewicza, ur. 17 IV 1933 r.; Alberta Szklarskiego, ur. 17 XII 1928 r.; Henryka Polberga, ur. 1 V 1935 r. w Bydgoszczy; Zdzisława Piotrowskiego, ur. 16 XI 1930 r. w Bydgoszczy; Franciszka Grzekalskiego, ur. 27 VII 1930 r. w Bydgoszczy; Władysława Kopydłowskiego, ur. 27 VIII 1931 r. (Aufnahmebuch Erziehungsanstalt Neustadt, nr 2515-2747).

${ }^{16}$ Józef Wiткошsкi, Obóz dla dzieci w Łodzi w systemie obozów hitlerowskich, [w:] Dzieci i młodzież w latach drugiej wojny światowej, s. 222-234; Joanna LeszczyńsKa, Łódzki obóz koncentracyjny dla dzieci, czyli sierociniec Himmlera, Rzeczpospolita, http://www.rp.pl/Plus-Minus/ 311179958-Lodzki-oboz-koncentracyjny-dla-dzieci-czyli-sierociniec-Himmlera.html (dostęp z 27 XII 2017 r.); Anna Gronczewska, Dramat malych więźniów niemieckiego obozu przy ul. Przemysłowej w Łodzi, Dziennik Łódzki, http://archive.is/Ar4cp (dostęp z 28 XII 2017 r.).

${ }^{17}$ OK.Gd., sygn. S 6/00/Zn, protokół przesłuchania świadka Franciszka Topolskiego, 23 III 2001 r., t. 2, s. 237-238; protokół przesłuchania świadka Jana Józefa Wiśniewskiego, 23 III 2001 r., t. 2, s. 246-247; protokół przesłuchania świadka Zdzisława Pietrowskiego, 24 IV 2001 r., t. 2, s. 263-264; protokół przesłuchania świadka Tadeusza Albina Ziółkowskiego, 13 VIII 2001 r., t. 2, s. 397-399; protokół przesłuchania świadka Rudolfa Tokarskiego, 15 VI 1990 r., t. 1, s. 4-5. 
darstwach, zmuszane były do wykonywania prac fizycznych na terenie przyległego do zakładu gospodarstwa rolnego, szwalni i pobliskich koszar wojskowych. Na terenie placówki prowadzone były dziecięce dyżury polegające na pracach porządkowych, pomocy w kuchni, rąbaniu drewna na opał. Niektóre dzieci wyplatały wiklinowe kosze (w budynku stodoły znajdującej się naprzeciwko pawilonu nr 2), robiły wycieraczki i maty, wypasały świnie i krowy. Pracę wykonywały sześć dni w tygodniu. Nadzór nad dziećmi sprawowali wychowawcy, którzy wobec dzieci niewykonujących norm stosowali kary cielesne polegające na biciu trzcinką lub pejczem. Za pracę na terenie zakładu dzieci nie otrzymywały wynagrodzenia. Praca i nauka odbywały się w systemie zmianowym. Tego dnia, w którym dzieci szły do pracy, inna grupa miała zajęcia szkolne. Czasami opiekunowie zapewniali dzieciom minimum rozrywki, tj. oglądanie filmów animowanych w języku niemieckim oraz sezonowo wyprawy na sanki lub basen.

Chłopcy z wejherowskiego zakładu pozostawali pod stałym nadzorem niemieckich wychowawców lub miejscowych Kaszubów. Opiekunowie, wyłącznie mężczyźni, w kontaktach z dziećmi zawsze używali języka niemieckiego. Kierownikiem placówki był Niemiec, funkcjonariusz SA, o nazwisku Engel. Wychowankowie zapamiętali go szczególnie, ponieważ utykał na jedną nogę. Znane są też nazwiska niektórych niemieckich wychowawców: Ponke vel Punke, Nacmer vel Natzner, Milewski, Samp, Formella. Opiekunowie na terenie zakładu zawsze nosili odzież cywilną. Każdy z wychowawców sprawował opiekę nad dziesięcioma chłopcami. Dzieci nazywały ich żartobliwie „ojczulkami”. We wspomnieniach dzieci wychowawcy jawią się jako osoby srogie, które za przewinienia potrafily nawet zbić kijem, pejczem lub ręką swych podopiecznych. Antoni Konkel złożył w tym temacie następujące zeznanie: „Czasami wychowawcy robili tzw. musztrę, ustawiali nas w dwuszeregu i kazali przez godzinę ćwiczyć "padnij», «powstań». Gdy już im się nie chciało mówić, to tylko pokazywali ręką. Niektórym chłopcom z wysiłku leciała krew z nosa. Wychowawcy stale nas popędzali, mieli laski i czasami uderzali. Ja też dostałem, gdy nie nadążałem w pracy"18. Jego zeznanie na ten temat uzupełnił Jan Bugajski: „Nasz wychowawca Necmer znęcał się nad dziećmi. Niejednokrotnie byłem świadkiem jak kopał on dzieci po całym ciele i po twarzy, a ponadto szturchał dzieci metalowym kluczem w różne części ciała. Mnie Necmer pobił przy obieraniu kartofli kijem od miotły. Bił mnie tym kijem po całym ciele i po głowie"19. Wychowawcy tolerowali też bicie się dzieci między sobą. Nigdy nie

${ }^{18}$ Ibid., sygn. S 6/00/Zn, protokół przesłuchania świadka Antoniego Konkela, 11 IV 1994 r., t. 1, s. 82 .

${ }^{19}$ Ibid., s. 81-83; protokół przesłuchania świadka Jana Bugajskiego, 5 IX 2001 r., t. 3, s. $444-448$. 
interweniowali, gdy słabszy był bardzo dotkliwie bity. Sporadycznie zdarzały się również przypadki ubliżania polskim dzieciom przez niemiecki personel pomocniczy, głównie nazywając ich „polskimi świniami”. Prawdopodobnie na terenie zakładu jeden z pokoi stanowił rodzaj karceru. Można było w nim zostać osadzonym za różne przewinienia, tj. powolną pracę lub niestosowną odzywkę do wychowawcy. Także wszystkie nieudane próby ucieczki z zakładu karane były pobytem w karcerze, po wcześniejszym zastosowaniu kary cielesnej. Chłopcy w izolatce zamykani byli w samej bieliźnie na czas do $10 \mathrm{dni}$. Dzieci, które przed osadzeniem w karcerze miały dłuższe włosy, były golone na łyso. Dostawały do jedzenia jedynie chleb i wodę do picia ${ }^{20}$.

Chłopcy uciekali stosunkowo często. Nigdy nie odnotowano ucieczki z terenu samego zakładu. Najłatwiej było oddalić się z miejsca pracy. Analizując wpisy do „Aufnahmebuch Erziehungsanstalt Neustadt”, można zauważyć, że niektóre dzieci przebywały poza ośrodkiem od kilku dni do kilku miesięcy. Trudno powiedzieć, gdzie w tym czasie się ukrywały, co jadły, gdzie spały. Znany jest jedynie los Bolesława Jażdżewskiego, który pracował w gospodarstwie Reimerów w Leśniewie. Uciekł pewnego dnia bezpośrednio z pola i udał się pieszo do domu rodzinnego w Kościerzynie. Pozostałe adnotacje poczynione w księdze ewidencyjnej mają jedynie postać lakonicznego wpisu o dacie ucieczki i dniu ponownego doprowadzenia do ośrodka, np. Alojzy Zieliński, uciekł 19 VI 1940 r., a doprowadzony został 4 VII 1940 r.; Wojciech Wincenty Połczyński, uciekł 21 VII 1941 r., doprowadzony został 28 VIII 1941 r.; Klemens Miciński, uciekł 21 IX 1941 r., doprowadzono go 6 I 1942 r.; Wacław Wrzesiński, uciekł 6 X 1941 r. a doprowadzony został dopiero 22 XII 1943 r. ${ }^{21}$

Polskie dzieci, w odróżnieniu od sąsiadujących z nimi niemieckich, nie miały prawa opuścić terenu zakładu. Z okien swoich sypialni obserwowały swobodnie bawiących się w parku młodych Niemców z Gauerziehungsheim. Jedynie w niedzielę organizowane były grupowe wyjścia do kościoła ewangelickiego na nabożeństwo. Niektórzy chłopcy w trakcie pobytu w zakładzie zostali przyjęci do pierwszej komunii świętej. Do sakramentu przystąpiły dwie grupy chłopców: osobno wyznania rzymskokatolickiego i osobno protestanckiego. Obowiązywał zakaz odwiedzin rodzin. Nawet listy wysyłane do domów

${ }^{20}$ Ibid., protokół przesłuchania świadka Antoniego Konkela, 31 I 1992 r., t. 1, s. 61; protokół przesłuchania świadka Bronisława Kachniarza, 20 III 2002 r., t. 3, s. 496-501; protokół przesłuchania świadka Bernarda Sarnowskiego, 24 VIII 2001 r., t. 3, s. 428-429; protokół przesłuchania świadka Bolesława Jeżdżewskiego, 20 VIII 2001 r., t. 3, s. 419-420; Aufnahmebuch Erziehungsanstalt Neustadt, nr 1-2223.

${ }^{21}$ Aufnahmebuch Erziehungsanstalt Neustadt, nr 1-2849; OK.Gd., sygn. S 6/00/Zn, protokół przesłuchania świadka Antoniego Konkela, 31 I 1992 r., t. 1, s. 59-60. 
były cenzurowane i musiały być napisane w języku niemieckim. Młodszym wychowankom listy do rodzin pomagali pisać wychowawcy. Przekazywali w nich jedynie lakoniczne wiadomości o stanie zdrowia i informowali o tym, że dziecko niczego nie potrzebuje.

Warunki bytowe w zakładzie były różnie oceniane przez przebywające tam dzieci. Jedni określali je jako znośne, gdyż mieli zapewnione trzy posiłki dziennie. W pierwszych miesiącach dyżurujące dzieci przynosiły posiłki z kuchni wojskowej z pobliskich koszar. Później zakład dysponował już własną kuchnią i stołówką. Drewno na opał rąbane było przez starszych chłopców (m.in. Antoniego Konkela). W kuchni zatrudnione były trzy kucharki dochodzące z Wejherowa. Wychowankowie wspominają, że bardzo często otrzymywali na śniadanie kawę zbożową, dwa kawałki chleba z marmoladą z brukwi, na obiad ziemniaki w mundurkach z sosem cebulowym i czasami niewielką ilość mięsa. Na kolację zaś zupę mleczną z dwoma kawałkami chleba. Czasami też byli dokarmiani sucharami przez żołnierzy zajmujących sąsiednie koszary. Budynek, w którym przebywały dzieci, był ogrzewany, skanalizowany i zaopatrzony w bieżącą wodę. Na korytarzach znajdowały się głośniki, przez które bardzo często były transmitowane wiadomości w języku niemieckim i piosenki niemieckie. W salach znajdowały się łóżka pojedyncze i piętrowe z siennikami ze słomy. Każdy z wychowanków miał zapewnione własne łóżko i pościel. Przy każdym łóżku znajdował się taboret, na który dzieci odkładały swoje ubrania. W pokojach nie było żadnych dodatkowych szaf ani stołów. Zakład zaopatrywał podopiecznych w odzież drelichową koloru niebieskiego, ze spodniami $\mathrm{z}$ białymi lampasami po boku. Ubrania były stosowne do pory roku. W niedzielę, w czasie wyjścia na nabożeństwo, chłopcy ubierali się w odświętne granatowe ubrania. Wielu wychowanków szczególnie źle wspomina konieczność chodzenia w butach, tzw. drewniakach. Obuwie to było pozbawione pięt, co było szczególnie uciążliwe w czasie wykonywania prac polowych w okresie zimowym. Warunki higieniczne też można określić jako wystarczające. W łazienkach stale było dostępne mydło, a raz w tygodniu chłopcy chodzili do łaźni do pobliskich koszar. Chłopcy byli objęci stałą opieką medyczną i dentystyczną lekarzy dochodzących do zakładu z innych placówek. Na terenie Erziehungsanstalt Neustadt nie było izby chorych. Dzieci, które wymagały hospitalizacji, zabierano do szpitala wojskowego. Bronisław Weinchold bardzo pozytywnie ocenił warunki panujące w zakładzie: „Warunki życia, jak na Dom Dziecka określam, że były bardzo dobre. Pamiętam, że spaliśmy w pokojach, w których były piętrowe łóżka. Spaliśmy na siennikach i przykrywaliśmy się kocami. Pościel, którą otrzymywaliśmy była bardzo czysta i często zmieniana. Nie pamiętam ile dzieci spało w jedne sali i ile dzieci było łącznie w zakładzie w Wejherowie. Otrzymywaliśmy 3 razy dziennie jedzenie, które było dobre i można się było dostatecznie najeść. Codziennie mieliśmy gimnastykę na 
podwórzu, a zimą jak było ciepło to też gimnastykowaliśmy się w ubraniach na podwórzu, a jak było zimno na korytarzach zakładu"22.

Większość wychowanków została zwolniona z zakładu w 1943 r. Część chłopców została przewieziona do obozu dla dzieci w Łodzi przy ul. Przemysłowej, do więzienia w Radogoszczy (Erweitertes Polizeigefängnis Radegast) oraz do wychowawczego obozu pracy, tzw. Szmalcówki w Toruniu przy ul. Grudziądzkiej. Niektóre zwolnione w tym czasie dzieci w uwagach miały zapisaną adnotację: „dalsze wychowanie w zakładzie opieki społecznej”. Niewielka liczba dzieci została przewieziona w okolice miejsca pochodzenia i tam przydzielona do pracy miejscowym gospodarzom. Taki los spotkał Pawła Balla, który z wejherowskiego ośrodka trafił do rolnika w okolice rodzinnego Drzycimia ${ }^{23}$. Natomiast Bernarda Falkowskiego latem 1944 r. przeniesiono do majątku koło Grabia w powiecie aleksandrowskim ${ }^{24}$. Zdarzały się też przypadki, że dzieci zostały zwolnione z zakładu i odesłane do domu rodzinnego po pozytywnym przejściu przez ich rodziców postępowania administracyjnego do tzw. niemieckiej listy narodowej.

W dokumentacji zakładu nie odnotowano żadnego zgonu wychowanka. Nie nastąpiły również przypadki zabójstw dzieci. W trakcie ostatecznej ewakuacji zakładu w styczniu 1945 r. w kierunku Torunia wyruszył personel z kilkoma pozostałymi jeszcze dziećmi. Część wychowanków uciekła w trakcie drogi, udając się głównie do domów rodzinnych. Pozostali po przejściu frontu zostali umieszczeni przez polskie władze w placówkach opiekuńczych jako ofiary wojny. Następnie po ustaleniu ich tożsamości były kierowane do domów rodzinnych, a w przypadku sierot - do zakładów opiekuńczych i domów dziecka ${ }^{25}$.

Obecnie w dawnym kompleksie budynków przy ul. Jana Sobieskiego w Wejherowie mieści się kilka instytucji. Jedną z nich jest położone przy ul. Sobieskiego 277 Centrum Wsparcia Teleinformatycznego i Dowodzenia Marynarki Wojennej. Kolejnymi są: Powiatowy Zespół Kształcenia Specjalnego (ul. Sobieskiego 279) i Powiatowe Centrum Pomocy Rodzinie (ul. Sobieskiego

${ }^{22}$ OK.Gd., sygn. S 6/00/Zn, protokół przesłuchania świadka Antoniego Konkela, 31 I 1992 r., t. 1, s. 59-60; protokół przesłuchania świadka Bronisława Weincholda, 6 XI 1991 r., t. 1, s. 34.

${ }^{23}$ Ibid., sygn. S 6/00/Zn, protokół przesłuchania świadka Pawła Balla, 16 VIII 2001 r., t. 3 , s. $413-415$.

${ }^{24}$ Ibid., sygn. S 6/00/Zn, protokół przesłuchania świadka Bernarda Falkowskiego, 23 III 2001 r., t. 2, s. $240-241$.

${ }^{25}$ Oddziałowa Komisja Ścigania Zbrodni przeciwko Narodowi Polskiemu w Łodzi, sygn. Ds. 281/67, śledztwo w sprawie zbrodni popełnionych na więźniach i młodzieży obozu przy ul. Przemysłowej w Łodzi, protokół przesłuchania świadka Tadeusza Baś, 14 I 1971 r., t. 7, s. 1269-1272; protokół przesłuchania świadka Józefa Baś, 16 I 1971 r., t. 7, s. 1273-1274; protokół przesłuchania świadka Henryka Baś, 18 I 1971 r., t. 7, s. 1271-1272. 
279A). W społeczności lokalnej Wejherowa przetrwała głównie wiedza na temat mieszczącego się w tym kompleksie budynków szpitala psychiatrycznego. Na temat istnienia w tym miejscu w okresie okupacji zakładu wychowawczego dla chłopców wiedza jest znikoma.

Nadesłany 5 IV 2017

Nadesłany po poprawkach recenzyjnych 3 I 2018

Zaakceptowany 25 III 2018

Dr Monika Tomkiewicz

Oddziałowa Komisja Ścigania Zbrodni przeciwko Narodowi Polskiemu w Gdańsku Instytut Pamięci Narodowej

e-mail: Monika.Tomkiewicz@ipn.gov.pl

ORCID ID: 0000-0001-5012-3699

\section{Childcare Centre for Polish Boys in Wejherowo DURING THE GERMAN OCCUPATION}

\section{Summary}

Key words: Neustadt, German childcare centres for Polish children, orphanages, territories incorporated into the Third Reich, everyday life in Gdańsk Pomerania during the German occupation

At the beginning of the German occupation in the territories incorporated into the Third Reich all the Polish orphanages and childcare centres became administered by the German authorities. It was in accordance with the incentives included in the book prepared by the Political-Racial Bureau in November 1939 titled The question of the treatment of the population from the former Polish territories from the racial-political point of view, which recommended that racially valuable children should be exempted from resettlements and should be brought up in the Reich in special educational centres which followed the model of the House of Orphans in Potsdam. On 9 September 1939 Wejherowo was taken over by German soldiers from the $207^{\text {th }}$ Infantry Division of Tiedemann, the $32^{\text {nd }}$ Regiment of Grenzwache von Bothmer, the SS Battalion Heimwehr Danzig of Major von Rittberg and the $5^{\text {th }}$ Cavalry Regiment of Diener. The Wejherowo land became part of the Reichsgau Danzig-West Prussia. The occupying forces took over the buildings of the pre-war Centre for Social Care and the Primary School for the Deaf and Mute in Wejherowo, which are now situated at 279 Jana Sobieskiego street (at that time: Adolf-Hitler-Strasse). The buildings served as accommodation for the military units. Buildings no. 2 and no. 4 along with the farm were not utilised. The German administration set up the Educational Centre called "Erziehungsanstalt Neustadt" for Polish and German boys aged 4 to 16 in the dormitory and school buildings. Polish children came from the territories of the former Pomeranian 
province - Bydgoszcz, Grudziądz, Toruń, Gdynia, Starogard Gdański and Kartuzy. The number of children of Polish nationality who stayed in the educational centre in Wejherowo amounted to 101 boys 9 according to the data of 31 April 1940). During their stay in the centre in Wejherowo boys were supervised by German teachers or local Kashubians. From time to time children were sent to nearby farms to help in agricultural works. In 1943 the decision was made to liquidate the centre gradually. Thirtyone boys were transported to the camp for children in Łodź in Przemysłowa street. During the evacuation of the centre some children escaped to their family homes. The remaining children were placed by the Polish authorities in childcare centres as victims of the war. Once their identity had been established, they were sent to their family homes. Orphans were placed in orphanages and childcare centres.

\section{Die ERZIEhUngSANSTALT FÜR POLNISCHE JUNGEN in Neustadt in Westpreussen in Der Zeit der deutschen Besatzung}

\section{Zusammenfassung}

Schlüsselwörter: Neustadt, deutsche Erziehungseinrichtungen für polnische Kinder, Waisenhäuser, vom Dritten Reich annektierte Gebiete, Alltagsleben im Danziger Pommern während der deutschen Besatzung

$\mathrm{Zu}$ Beginn der deutschen Besatzung wurden auf den vom Dritten Reich annektierten Gebieten alle polnischen Waisenhäuser und Erziehungseinrichtungen unter deutsche Verwaltung gestellt. Dies entsprach den Richtlinien in einem Papier des Rassepolitischen Amtes aus dem November 1939 mit dem Titel „Die Behandlung der Bevölkerung in ehemaligen polnischen Gebieten aus rassepolitischer Sicht“, in der empfohlen wurde, rassisch wertvolle Kinder von Umsiedlungen auszunehmen. Sie sollten auf dem Gebiet des Reichs in entsprechenden Erziehungsanstalten erzogen werden, die sich am Vorbild des Waisenhauses in Potsdam orientierten. Am 9. September 1939 wurde Neustadt von deutschen Soldaten der 207. Infanteriedivision unter Carl von Tiedemann, dem 32. Grenzwach-Regiment unter Freiherr von Bothmer, dem SS-Bataillon Heimwehr Danzig unter Major von Rittberg und dem 5. Kavallerie-Regiment unter Oberstleutnant Diener eingenommen. Das Gebiet von Neustadt wurde dem Reichsgau Danzig-Westpreußen einverleibt. Die Besatzungsbehörden übernahmen die Gebäude eines Pflegeheims und einer Grundschule für Taubstumme in Neustadt, die heute in der ul. Jana Sobieskiego 279 (damals Adolf-Hitler-Straße) liegen, und bestimmten sie für die Einquartierung von Armeeabteilungen. Unbewirtschaftet blieben die Häuser mit den Nummern 2 und 4 sowie eine Landwirtschaft. Im Internat und in den Schulgebäuden eröffnete die deutsche Verwaltung eine Erziehungseinrichtung mit dem Namen „Erziehungsanstalt Neustadt“ für polnische und deutsche Jungen im Alter von 4 bis 16 Jahren. Die polnischen Kinder kamen aus dem Gebiet der ehemaligen Wojewodschaft Pommern, d.h. aus Bromberg, Graudenz, Thorn, Gdingen, Stargard, Danzig und Karthaus. Die Zahl der Kinder polnischer Nationalität in der Anstalt in Neustadt betrug nach Angaben vom 31. April 1940101 Jungen. Während 
des Aufenthalts in der Anstalt in Neustadt standen die Jungen unter ständiger Aufsicht von deutschen Erziehern oder örtlichen Kaschuben. Manchmal erhielten die Kinder Urlaub und arbeiteten dann in nahegelegenen Landwirtschaftsbetrieben. 1943 wurde entschieden die Anstalt schrittweise aufzulösen. 31 Jungen wurden in ein Lager für Kinder in Lodz in der ul. Przemysłowa gebracht. Im Verlauf der Evakuierung der Anstalt flohen einige Kinder und gelangten hauptsächlich in ihre Elternhäuser. Der übrige Teil wurde nach dem Durchgang der Front von den polnischen Behörden als Kriegsopfer in Betreuungsanstalten untergebracht, von wo sie nach Feststellung ihrer Identität in ihre Elternhäuser gebracht wurden bzw. im Fall von Waisen in Betreuungsanstalten und Kinderheime.

\section{Bibliografia}

Borzyszkowski, Józef, ed. Historia Wejherowa. Wejherowo: Muzeum Piśmiennictwa i Muzyki Kaszubsko-Pomorskiej, 1998.

Ciechanowski, Konrad. Obozy hitlerowskie na Pomorzu w latach 1939-1945 nie podlegające Inspektoratowi Obozów Koncentracyjnych - stan badań i postulaty badawcze. Gdańsk: Sesje naukowe Okręgowej Komisji Badania Zbrodni przeciwko Narodowi Polskiemu w Gdańsku, unpublished, 1987.

Ciechanowski, Konrad. "Okupacyjne losy polskich dzieci i młodzieży na Pomorzu Gdańskim.” In Dzieci i młodzież w latach drugiej wojny światowej, edited by Czesław Pilichowski. Warszawa: Państwowe Wydawnictwo Naukowe, 1982.

Daniluk, Jan. SS w Gdańsku. Gdańsk: Instytut Pamięci Narodowej, 2013.

Gronczewska, Anna. "Dramat małych więźniów niemieckiego obozu przy ul. Przemysłowej w Łodzi.” Dziennik Łódzki. Access December 28, 2017. http://archive. is/Ar4cp.

Jastrzębski, Włodzimierz and Sziling Jan. Okupacja hitlerowska na Pomorzu Gdańskim w latach 1939-1945. Gdańsk: Wydawnictwo Morskie, 1979.

Historia Ośrodka Szkolno-Wychowawczego nr 2 dla Głuchych im. J. Siestrzńskiego $w$ Wejherowie. Wejherowo, 1991.

Hrabar, Roman Z. Hitlerowski rabunek dzieci polskich. Uprowadzanie i germanizowanie dzieci polskich w latach 1939-1945, Katowice: Śląsk, 1960.

Hrabar, Roman Z. Janczarowie XX wieku. Katowice: Śląsk, 1983.

Kaczmarek, Ryszard. "Niemiecka polityka narodowościowa na Górnym Śląsku (1939-1945).” Pamięć i Sprawiedliwość 2 (6) (2004): 115-138.

Kotewicz, Józef. "Pięćdziesięciolecie ośrodka szkolno-wychowawczego nr 2 dla głuchych w Wejherowie". In Biblioteka Muzeum Piśmiennictwa i Muzyki KaszubskoPomorskiej w Wejherowie, 67, Wejherowo: Muzeum Piśmiennictwa i Muzyki Kaszubsko-Pomorskiej w Wejherowie 1983.

Krauss, P. Damals. Heimwehr Danzig. Erinnerungen und Begegnungen. Cobburg, 1982. Leszczyńska, Joanna. “Łódzki obóz koncentracyjny dla dzieci, czyli sierociniec Himmlera.” Rzeczpospolita. Access December 27, 2017. http://www.rp.pl/Plus-Minus/ 
311179958-Lodzki-oboz-koncentracyjny-dla-dzieci-czyli-sierociniec-Himmlera. html.

Leszczyński, Edward. Sonderbehandlung. Zbrodnia na polskich dzieciach. Wrocław: Wydawnictwo „Wektory”, 2014.

Michaelis, Rolf. SS-Heimwehr Danzig 1939. Warszawa: Militaria, 2003.

Milczewski, Zygmunt. Wejherowo i powiat morski wrzesień 1939 - maj 1945 (kronika). Gdańsk, 1991.

Osowicka, Regina. "Matki mdlały z rozpaczy, sieroty z głodu jadły śnieg. Odyseja „polskich dzieci syberyjskich" przez Japonię do Wejherowa." Dziennik Bałtycki (1994): 7.

Porożyński, Henryk. Zakład Poprawczy w Chojnicach w latach 1885-1985. Słupsk: Wyższa Szkoła Pedagogiczna, 1991.

Pospieszalski, Karol Marian. Niemiecka Lista Narodowa w „Kraju Warty” (Documenta Occupationis Teutonicae, t. 4). Poznań: Instytut Zachodni, 1949.

Witkowski, Józef. “Dziecko w systemie hitlerowskim.” In Człowiek, populacja, środowisko. Prace Dolnośląskiego Centrum Diagnostyki Medycznej „Dolmed” we Wrocławiu. Wrocław, 1988.

Witkowski, Józef. Hitlerowski obóz koncentracyjny dla małoletnich $w$ Łodzi. Wrocław: Zakład Narodowy im. Ossolińskich, 1975.

Witkowski, Józef. “Obóz dla dzieci w Łodzi w systemie obozów hitlerowskich." In Dzieci i młodzież w latach drugiej wojny światowej, ed. Czesław Pilichowski. Warszawa: Państwowe Wydawnictwo Naukowe, 1982.

Wnuk, Józef, Helena Radomska-Strzemecka. Dzieci polskie oskarżają 1939-1945. Warszawa: Pax, 1961.

Ziemia wejherowska. Gdańsk: Wydawnictwo Morskie, 1980. 